\title{
SME Roles in Modular Value Chains: Perspectives for Growth and Innovativeness
}

\author{
Marta Gancarczyk, Jacek Gancarczyk, Joanna Bohatkiewicz
}

\begin{abstract}
A B S T R A C T
Objective: The aim of the paper is to present modular value chains (MVCs) as a technological and organisational phenomenon that affects industrial organisation and innovation, and to identify the characteristics and types of SME positions (roles) in modular value chains that are associated with innovation development and growth.

Research Design \& Methods: The study employs two methods, which are literature review and a multiple-case study approach based on two SMEs in the IT industry of which one acts as an independent innovator generating proprietary solutions and the other one is a supplier of production capacity in the area of lower to medium value-adding solutions.

Findings: SME roles in modular value chains range from lowest-tire subcontractors in captive or market-based governance to major roles typical of large players in modular governance, e.g., quasi-lead firms and quasi-contract manufacturers. The latter two roles are associated with innovation and high growth.

Implications \& Recommendations: The recommendations as to the role of public policy and geographical context are provided regarding how to facilitate SMEs' integration into MVCs with a focus on innovativeness and expansion. The question for further research is whether the roles identified in the case studies can be treated as SME-specific models of participation in modular value chains, or are they only development stages of growth SMEs towards the roles of large firms leader firms and contract manufacturers (system integrators).
\end{abstract}

Contribution \& Value Added: The paper contributes by identifying the roles that SMEs can play in modular value chains and by identifying governance arrangements that SMEs apply to accomplish innovation and high growth.

\section{Article type: research paper}

Keywords: modularisation; growth; innovativeness; SMEs; global value chains

JEL codes: $\quad$ M16, M21, L14

Received: 3 April 2017

Revised: 20 May 2017

Accepted: 9 June 2017

\section{Suggested citation:}

Gancarczyk M., Gancarczyk J., \& Bohatkiewicz J. (2017). SME Roles in Modular Value Chains: Perspectives for Growth and Innovativeness. Entrepreneurial Business and Economics Review, 5(3), 95-117. http://doi.org/10.15678/EBER.2017.050305 


\section{INTRODUCTION}

Technological developments have been one of the major determinants of the efficient scale of company operations and growth, as well as factors influencing the importance of SME sector in the economy. The increasingly important trend of modular product development, design and engineering strongly impacted SME participation in global production networks and global value chains (GVCS) (Baldwin \& Clark, 2000; Sanchez \& Mahoney, 1996; Lau, 2011; Langlois, 2002; Sturgeon, 2002; 2003). The positions (roles) of SMEs in modular value chains (MVCs) as well as their prospects for innovativeness and growth are under-researched, since the literature on modularity in the organisation of industries and networks focuses on large enterprises as major players in the global governance (Sturgeon, 2002; 2003; Ivarsson \& Alvstam, 2011; Lee \& Saxenian, 2008; Kodama \& Shibata, 2013; Simms \& Trott, 2014; Yan, Chiang, \& Chien, 2014; Pietrobelli \& Rabellotti, 2006). Moreover, there is a controversy in two important literature streams as to development prospects for SMEs in global networks. In the global value chains (GVCs) literature, SMEs are predominantly seen as lowest-tier providers that occupy lower-value positions and struggle for survival due to cost competition, low margins, and high transaction costs (Humphrey \& Schmitz, 2002; 2004a; Belaya \& Hanf, 2014; Lungwitz, Lee, \& Campagna, 2006; Gancarczyk, 2016). On the other hand, the literature in international entrepreneurship presents SMEs as proactive global players that accomplish expansion through innovation (McDougall \& Oviatt, 2000; Oviatt \& McDougall, 2005; Coviello \& Munro, 1997; Coviello, 2006; Gancarczyk \& Gancarczyk, 2011; 2017).

In response to the above literature gap and unresolved issues, the aim of this paper is to present modular value chains as a technological and organisational phenomenon that affects industrial organisation and innovation, and to identify the characteristics and types of SME positions (roles) in modular value chains that are associated with innovation development and growth. This aim is addressed with two methods, namely, literature review and a multiple-case study approach based on two SMEs in the IT industry of which one acts as an independent innovator generating proprietary solutions and the other one is a supplier of production capacity in the area of lower to medium value-adding solutions.

The results of our investigations point to a variety of roles that small and mediumsized enterprises may adopt in MVCs, as they are not only in lowest-tire subcontracting relations, but may also assume major roles, attributed predominantly to large enterprises, such as lead firms and contract manufacturers or contract producers.

The paper contributes by identifying the roles that SMEs can play in modular value chains and by describing the governance arrangements that SMEs apply to accomplish innovation and high growth. Moreover, recommendations as to the role of public policy and geographical context are provided regarding how to facilitate SMEs' integration into MVCs with a focus on innovativeness and expansion.

The second section presents theoretical framework of modularity as a technological and organisational phenomenon and describes SME positions in global value chains according to the GVC and international entrepreneurship perspectives. As a result of this literature review, three research questions were formulated to guide the empirical investigations. After explaining the methodology of empirical research 
in the third section, we implement it and present results of two case studies in section four. Discussion and conclusions follow in the fifth section.

\section{LITERATURE REVIEW}

\section{Modularity as a Technological and Organisational Phenomenon}

Modularisation originated from technological changes in product development, design and engineering that affected the organisation of production in firms and industries, and the overall industrial organisation (Sanchez \& Mahoney, 1996; Langlois, 2002; Garud, Kumaraswamy, \& Langlois, 2009). The impact of technological changes on economic organisation, so called "mirroring effect", was supported by the empirical research as one of the major determinants of economic organisation (Frenken \& Mendritzki, 2012; Hoetker, 2006; Sanchez \& Mahoney, 2013). It is also suggested that the advantages of modularisation, i.e. specialisation and flexibility, can be fully exploited only when firms and industries adopt the modular approach both to technology and organisation (Frenken \& Mendritzki, 2012; Hoetker, 2006; Sanchez \& Mahoney, 2013).

Modularisation as a technological and organisational phenomenon was developing since the 80. through the 90., primarily in the USA electronics and IT industries. Standardisation and flexible technologies enabled customized and short-series supplies, leading to the fragmentation of product engineering, design, and manufacturing (Sturgeon, 2002; 2003). Modularisation in technology includes dividing a complex product or service into separate functional elements (modules, subsystems) that can be developed, designed, engineered, and manufactured separately, due to limited functional interdependencies (Baldwin \& Clark, 2000; Sanchez \& Mahoney, 1996; Lau, 2011; Gancarczyk \& Gancarczyk, 2013). In order to enable these elements to act as a whole, the interfaces and functions of separate modules are specified and highly codified, which is enhanced by de facto standards and computer-aided tools, such as CAM, CAE, CAD, SCM (Ulrich \& Eppinger, 2000; Funk, 2009). This technological pattern accelerates product improvements by disintegration of the innovation process into separate organisations that are responsible for specific modules. The modular development and design allow for a huge number of product advancements within product functional elements and for the configurations of different types of modules that affect the overall product features, however, with little impact on its overall architecture.

The fragmentation of product technological development and manufacturing stimulated a new organisation of production and value chain governance (Sanchez \& Mahoney, 2013; 1996; Henderson \& Clark, 1990; Colfer, 2007; Colfer \& Baldwin, 2010; Battisti, Colombo, \& Rabbiosi, 2014). The modular pattern of product development and engineering enabled dividing the value chain into separate functional elements for which individual companies could be responsible (Langlois, 2002; Sturgeon, $2002 ; 2003)$. Other determinants of this new organisation of production included the needs to coordinate the dispersed global production chains and to avoid the risks associated with manufacturing due to the rapid changes in demand and technology. One response to these needs was deverticalization (vertical disintegration) and outsourcing by branded original equipment manufacturers (OEMs) to focus on higher value adding activities. The result was a rise of lead firms dealing with product innovations, design 
and marketing. Another response was the emergence of contract manufacturers (or contract producers $)^{1}$ dealing with engineering, process innovations, and logistics, and their horizontal integration to accomplish economies of scale (Baldwin, 2008; Gangnes \& Assche, 2004; Lau, 2011). Contract manufacturers coordinate the global value chain of their own subsidiaries and those of other suppliers (Sturgeon, 2003).

To sum up, modular value chain is a system of the organisation of production that consists of the specialisation of companies in particular value chain activities (modules) of a complex product and in their horizontal integration within this specialisation (Gancarczyk \& Gancarczyk, 2013; Gancarczyk, 2015). The modular pattern is not restricted to complex products in high-technology industries, such as electronics, ICT, and pharmaceuticals, but it can also be found in more mature and lower-technology industries, including automobiles, plastic products, and food, among others (Gangnes \& Assche, 2004; Lau, 2011). Therefore, the modular mode of governance is treated as the latest and dominant form of the global value chain governance and even synonymous with the GVC governance (Lee \& Saxenian, 2008; Sturgeon, Biesebroeck, \& Gereffi, 2008; Gereffi, Humphrey, \& Sturgeon, 2005).

\section{SMEs in Modular Value Chains}

The GVC governance is understood as the coordination of all functional activities that create product value, while these activities involve more than one country (Humphrey \& Schmitz, 2002; 2004a; Humphrey \& Schmitz, 2002; Gereffi et al., 2005; Pietrobelli \& Rabellotti, 2011). The global value chain literature focuses on how different types of governance modes impact the possibilities for learning, innovative outcome, upgrading, and ultimately, for growth of contracting partners, specifically suppliers from less developed economies that occupy lower value adding functions (Gereffi, 1996; Humphrey \& Schmitz, 2002; Humphrey \& Schmitz, 2004a; Humphrey \& Schmitz, 2004b; Gereffi et al., 2005; Sturgeon et al., 2008).

Upgrading denotes the improvement of relative competitive position due to the development of capabilities in the area of products, processes, functions and value chain governance to advance into more sophisticated, higher value-adding activities (Gereffi, 1996; Humphrey \& Schmitz, 2002; Humphrey \& Schmitz, 2004a; Humphrey \& Schmitz, 2004b; Gancarczyk \& Gancarczyk, 2016). There is a direct relationship between upgrading and innovation development. The latter can be treated as a condition leading to the ultimate effect of upgrading. In this vein, product, process, and organisational innovations and configurations of these generic forms of innovation may result in adequate types of upgrading (Kaplinsky \& Morris, 2001; Kaplinsky, Morris, \& Readman, 2002; OECD, 2005).

The analytical framework of GVC comprises of three components that explain the position and growth prospects of firms and industries, namely: inter-firm chain governance, power relations, and institutions (Sturgeon et al., 2008). In the view of the global value chain approach, inter-firm governance is a source of competitive advantage (Kaplinsky \& Morris, 2001; Kaplinsky et al., 2002; Gereffi et al., 2005; Williamson, 1999; 2002; 2005). Therefore, supplier development and upgrading depend on the governance solutions applied. The governance, in turn, implies power relations among contracting parties in the value chain. These relations are strongly affected by asset specificity, which means that

\footnotetext{
${ }^{1}$ Modularity governs both manufacturing and service industries. Therefore, we will use the expression "contract manufacturers" for manufacturing industries and the expression "contract producers" for service industries to denote suppliers of manufacturing or service activities, accordingly.
} 
firm resources are adjusted to the requirements of an individual transaction and they cannot be redeployed in a new exchange without losing their productive value (Williamson, 1975; 1999; 2002). Specific assets raise dependence and contractual hazards for the partner who incurs a larger specific investment (Williamson, 1975; 1991; 1999; 2002; Humphrey \& Schmitz, 2002; Huggins \& Johnston, 2010). Institutions are norms and rules which regulate behaviours and activities of individuals, firms and industries. The institutions, such as labour unions, industry associations, legal and cultural norms industry-specific standards, and contracting arrangements form a framework affecting how the specific inter-firm governance and power relations function (Lee \& Saxenian, 2008).

According to the GVC approach, three major variables, namely transaction complexity, codification of transaction and supplier capabilities, determine the emergence of four structures of inter-firm governance, including market, captive, relational and modular value chains (Gereffi et al., 2005; Sturgeon et al., 2008). Transaction complexity is the amount of information that needs to be exchanged between partners, while formalisation represents the degree to which this information is codified in a specific exchange (Gereffi et al., 2005). Capabilities denote supplier's resources and competences in relation to the requirements of collaborating with a given customer (Gereffi et al., 2005; Sturgeon et al., 2008).

Various configurations of these three variables affect the emergence of specific types of value chain governance and power relations that may lead to the innovative output and upgrading or impede these results.

Market, price-based value chains emerge when transaction complexity is low and its formalisation is high, while a supplier demonstrates high capabilities. Power relations, due to low asset specificity, remain balanced and do not cause any dependence of the parties. This governance does not involve deeper interaction and knowledge exchange to stimulate innovative outcome in the area of product, but it may result in process innovations directed at cost reduction and efficiency of deliveries.

Captive value chains are featured by high transaction complexity and codification and low supplier capabilities and they provide a limited opportunity to upgrade (Gereffi et al., 2005). The lead company provides a technology and specifies the standards of production and supplies, which stimulates process innovations. Such a relationship implies the threat of idiosyncratic investment and locking the subcontractor in the standardised, lower value-adding activity in global value chains (Rugraf, 2010; Pavlínek, 2012; Gancarczyk, 2015; Gancarczyk \& Gancarczyk, 2013). Due to asset specificity, power relations are uneven, leaving the supplier at a disadvantaged position.

In modular value chains (high transaction complexity and technology codification, and high subcontractor capabilities) and relational chains (high transaction complexity but low codification) a lead company formulates requirements as to product characteristics and a supplier offers its own engineering and design to meet these expectations and to benefit from upgrading (Humphrey \& Schmitz, 2004b; Winter, 2010; Gereffi et al., 2005).

Relational value chains involve close interaction and tacit knowledge exchange due to low formalisation, leading to incremental product and process innovations and related upgrading types. Specific assets required from the supplier threaten the balance of power. However, the balanced relations still can be accomplished based on a similar level of competence between partners and adequate institutions (norms, rules, contractual arrangements) that prevent opportunism. 
Modular value chains differentiate from the relational pattern by high formalisation of transaction that involves little direct interaction between two major players. These are lead firms and their major first-tier suppliers, i.e. contract manufacturers/producers (system integrators, maestros, orchestrators) that offer a comprehensive ("turn-key") coordination of production. These relationships feature balanced power and intense flow of codified knowledge, which enables process innovations and functional upgrading of contract manufacturers based on backward and forward integration.

In modular value chains, much less attention is given to lower-tier suppliers providing standardised components and services to contract manufacturers. In the industry structure dominated by lead companies and contract manufacturers, the weakest bargaining power is possessed by small and medium-sized companies ${ }^{2}$ from the lower-cost locations (Belaya \& Hanf, 2014; Lungwitz et al., 2006; Gancarczyk, 2016). Such companies experience cost and margin pressures from contract manufacturers who globally coordinate suppliers competing for business. Moreover, there are minor opportunities for those suppliers to absorb knowledge and technology from their buyers, as they implement standardised and reduced activities, giving merely the opportunities for incremental process innovations. SMEs may bear excessive transaction costs from idiosyncratic investments. Moreover, they encounter dependence that causes the opportunistic behaviours of larger customer, including unfavourable terms of contracts as well as externalizing risks and costs (Humphrey \& Schmitz, 2002; 2004a). Being a part of modular value chains dominated by two large players: lead firms and contract manufacturers, SMEs are considered as exposed to different governance arrangements. Namely, their relationships are perceived as locked in market-based or captive governance linked to the lowest tiers of modular chains (Belaya \& Hanf, 2014; Lungwitz et al., 2006; Pisoni, Fratocchi, \& Onetti, 2013).

However, the GVC approach is not deterministic in its assumptions about the impact of the extant governance mode on the supplier firm and industry positions and development prospects (Mudambi, 2008; Malecki, 2010). It points to the dynamics and evolution of the position of firms and industries in global value chains due to the changes in one or more determinants of governance, such as supplier capability, level of complexity, or formalisation (Sturgeon et al., 2008; Hätönen, 2010). Recent advances in technology and the opportunity of networking to access lacking and complementary resources act in favour of smaller-scale operations (Agostino, Giunta, Nugent, Scalera, \& Trivieri, 2015; Aslesen \& Harirchi, 2015; Massini, Perm-Ajchariyawong, \& Lewin, 2010; Cusmano, Mancusi, \& Morrison, 2011). As a consequence, SMEs may operate as network leaders, coordinating at least parts of the value chain of a good in the form of modules, such as subsystems of the IT architecture (Hätönen, 2010; Alberti, Sciascia, Tripodi, \& Visconti, 2008). They are also capable of breakthrough product innovations, assuming the role attributed to lead firms. In the view of international entrepreneurship, SMEs increasingly pursue global expansion and proactively exploit opportunities in global value chains with a focus on growth (McDougall \& Oviatt, 2000; Oviatt \& McDougall, 2005; Coviello \& Munro, 1997; Coviello, 2006). These advancements enable small and medium-sized

\footnotetext{
${ }^{2}$ We apply the definition of SMEs included in the EU Commission Recommendation 2003/361/E. This definition is based on the criteria of employment (fewer than 250 persons), annual turnover not exceeding EUR 50 million, and/or an annual balance sheet total not exceeding EUR 43 million.
} 
enterprises to escape from either exclusively market or captive relations in the lowest tiers of modular production chains (Gancarczyk \& Gancarczyk, 2017).

Despite the increasingly global reach of SME operations, there is limited research evidence on the processes and ways of SME successful growth and innovation development within modular value chains (Hätönen, 2010; Pietrobelli \& Rabellotti, 2006; Ahlin, Drnovšek, \& Hisrich, 2014). Majority of studies focus on large corporations and on the cases of upgrading of the entire industries (Ivarsson \& Alvstam, 2011; Lee \& Saxenian, 2008; Kodama \& Shibata, 2013; Simms \& Trott, 2014; Yan et al., 2014). Also, the extant research on SME growth is inconclusive about the impact of networks in this process and it does not comprehensively highlight how they accomplish expansion when operating in networks and global value chains. High-growers are reported to adopt a niche market position and benefit from customers undertaking international expansion (Storey, 1994; Barringer \& Neubaum, 2005; Gilbert et al., 2006; Dobbs \& Hamilton, 2007). This reflects the traditional Penrosian view of firm growth, which is still a relevant approach to SMEs in local or regional markets, but it is less efficient in explaining global expansion and networked economy (Penrose, 1959). Little is known about roles, inter-firm governance, power structures, and institutions that are associated with innovative growth of SMEs in global and, specifically, modular value chains (Hätönen, 2010). The global scope of modular value chains challenges the view of SMEs operating in the niches left by large firms. SMEs inserted in the networks of large global enterprises can be either passive players at the captive, disadvantaged position, or they may use networks of large firms as global pipelines to implement own innovation-upgrading and growth strategies (Munari, Sobrero, \& Malipiero, 2011; Gancarczyk \& Gancarczyk, 2017).

The current state of the research on the emerging roles of innovative and highgrowth $^{3}$ SMEs justifies formulating three explorative research questions:

1. What characteristics of inter-firm governance, power relations, and institutional arrangements are associated with SME innovations and growth in modular value chains?

2. What types of inter-firm governance, power relations, innovation and upgrading are implemented by growth SMEs in modular value chains?

3. What types of growth SME roles (positions) in modular value chains can be identified based on the pattern-matching approach?

\section{MATERIAL AND METHODS}

The above research questions feature exploratory nature and complexity due to a large number of factors they involve and the importance of context to describe the position of growth SMEs in modular value chains. The multitude of factors need to be considered and translated into empirical variables to comprehensively define this position. Namely, the factors that determine inter-firm governance and the value chain mode are transaction complexity and formalisation, and SME capability, while power relations are determined by asset specificity. Innovative activities and their potential outcome in the form of upgrading need to be considered according to different types (product, process, organisation innovation; product, process, functional, and value chain upgrading). Moreo-

\footnotetext{
${ }^{3}$ We use the terms of "growth firm" or "high-growth firms" interchangeably.
} 
ver, the institutional context reflected in the external rules and norms at the macro, industrial- and inter-firm levels should to be taken into account. This requires the investigation of country-level regulations, industrial standards and norms, private, bilateral contractual arrangements, and safeguards to contracts, among others.

Considering the properties of the study object, we adopt a multiple-case method to describe and identify the positions of two SMEs in modular value chains based on the GVC approach (Yin, 2003; Silverman, 2005; Eisenhardt \& Graebner, 2007). Following a patternmatching approach, we compare and match the characteristics of the GVC factors in the case study with the theoretical assumptions (Langley, 1999; Lee, 1989; Campbell 1966; Yin, 2003). This enables the identification of the types of the value chain governance and the types of roles (lead firms, contract manufacturers, and lower-tier suppliers). The outcome of our analysis will be an analytical generalisation about the characteristics of the GVC governance pattern for high-growth SMEs involved in modular value chains (Eisenhardt, 1989). A case study approach can only result in analytical generalisation as a weak form of generalisation relative to the statistical one. This represents a natural limitation of the methodology applied. On the other hand, our investigation is guided by three exploratory research questions formulated based on the literature review in the second section of the paper. It is intended that responding to these questions will establish a basis for research hypotheses in further, quantitative research directed at statistical generalisation.

A purposeful and theory-driven selection of case study companies was performed (Yin, 2003; Silverman, 2005; Eisenhardt \& Graebner, 2007). We chose firms with characteristics of high-growers according to sales and employment increase (at least doubling sales and employment within three years (2010-2012). Moreover, the companies needed to act in modular value chains, therefore firms were picked up from one of the core industries with modular design by technology and organisation, namely, the IT industry in the area of services and software development. The major sources of data included the primary sources from direct and structured interviews with entrepreneurs, each lasting around two hours. The secondary sources were webpages and press releases that enabled the triangulation of the data obtained.

\section{RESULTS AND DISCUSSION}

\section{The Case of SoftCo}

SoftCo is a Polish medium-sized firm that employs around 70 people including more than 50 engineers in the area of information technology and electronics. It was established in 2007 as a venture of an IT engineer and scientist from Warsaw University of Technology. The venture originated from the former research and development laboratory established by another corporation, a mid-size technology firm. The commercial potential of the laboratory was identified by its former leader and current entrepreneur and CEO at the same time.

In the years 2010-2012, the compound revenue growth of the company exceeded $262 \%$ and employment grew by more than $100 \%$. SoftCo applied both organic and external growth through acquisitions of two micro-size technology firms in the related software technology. The expansion was associated with introducing new products to new groups of customers and building the portfolio around the core competence in the area of original software development. SoftCo is a supplier to Polish 
leading media and energy corporations of international reach, expanding to countries of Central and Eastern Europe. Moreover, it has developed a collaboration with a number of global American semiconductor companies in Silicon Valley.

The first phase of development, in the years 2007-2010, was an Internet content distribution system for media, including the Internet TV, which dominated Polish market. The next development phase, since 2011, has focused on smart grid technology for energy distribution purposes. As a supplier to a leading Polish energy distributor, SoftCo has developed a software for smart meters (energy measurement). Their application enables reducing the number of hardware components in electricity meters and other components used in smart grids. Another emerging area of the company expansion in the form of new products is the Internet safety systems.

\section{The Inter-firm Governance}

\section{Transaction Complexity}

Transaction complexity, understood as the amount of information needed to implement a given contract, is high in the activities of SoftCo. This is associated with the complexity of technology used as the company provides software solutions to high-technology products and services, such as energy meters or media content delivery. The company provides complementary software solutions to complex, high technology products and services, which requires following adequate standards and interfaces to ensure the required functionality and compatibility with the overall architectures of these systems.

\section{Transaction Formalisation}

High complexity of implementing a contract is associated with high formalisation of the information exchanged with partners in the IT industry. The formalised information relates to standards and interfaces, which are general purpose and widespread technologies. More tacit knowledge and less formalised information needs to be exchanged with corporate customers in the industries to which the firm provides solutions. These solutions are often new and uncertain and require negotiating and establishing rules of cooperation, expected efficiencies and technological functions, as well as benefits for both contracting partners. In the latter case, SoftCo needs to maintain an intense and direct communication to establish the cooperation at the outset. However, the rules are formalised alike technological solutions generated as project results. Consequently, a high to medium level of transaction formalisation can be observed.

\section{Capability}

The company demonstrates high capability to develop proprietary software products and to fulfil the standards required by customers on a global scale. The geographical scope and originality of innovations ranges from Polish to the world market, the level of newness typical of firms operating in high-technology industries.

\section{Relationships in Value Chain and the Scope of Activities}

SoftCo is directed at growth as a technological firm commercialising the intellectual property in the form of licensing and it is not going to be involved in manufacturing activities. The necessary manufacturing activities are outsourced from contract manu- 
facturers (e.g., in Czech Republic). The company focuses on product development and commercialising with a goal to provide original product innovations in Polish, Central European, and global markets. The activities for Polish customers of international reach provide the firm with an opportunity to experiment with proprietary solutions and learn how these new and uncertain technologies will act. The entrepreneur and the firm leader clearly declares not to act as a subcontractor adopting the external technology, but as a technology developer that competes in the area of breakthrough innovations on a global scale with a focus on own brand building and growth.

\section{Power Relations - Asset Specificity}

The firm purposefully selects open standards for developing its applications to avoid the expensive licensing policy, constraints to technological modifications, and legal protection problems that may arise in the case of using proprietary, de facto standards of other firms. Another strong argument in favour of this policy is a comparable quality and functionality of the existing standards together with the ease of adaptability to their parameters. Therefore, the freedom and low cost of use, as well as accessibility play a major role rather than the identity and brand of the provider. Considering the above characteristics, SoftCo does not employ specific assets to adapt to its suppliers, since their technologies are general purpose and standard. The firm applies these standards as channels, global pipelines to distribute its complementary applications and thus, benefit from network effects due to the increased number of users. Another group of customers are corporations which use products and services adopting SoftCo applications (incidents of medium asset specificity). The firm responds to the required functionalities of the customers, however, the solutions demonstrate adaptability to other customers with minor changes. To sum up, we can describe SoftCo's power relations with business partners as free from high asset specificity and balanced. Therefore, these relations do not raise dependence or a threat of opportunistic behaviour from the partners.

\section{Institutional Framework}

In business relations with non-IT long-term customers, the company predominantly adopts formal and long-term contracts. The specifications and detailed terms of contracts are to protect the customer who is less knowledgeable in the area of technology and experiences information asymmetry. The collaboration with other IT firms is of a networking and relational nature, based on repetitive transactions. Mutuality, trust, and partnership govern the relations and are seen as the major rules of cooperation rather than hard incentives in formal contracts. SoftCo seeks to maintain technological and organisational independence from foreign collaborators and competitors.

Industrial institutional environment is featured by density of open standards with regard to technology and its legal protection. The firm actively involves in setting up technological standards, however, this complex process is by no means limited to technological rules and formalisations. In order to establish technological standards, such as in the case of energy smart meters, the SoftCo CEO builds a larger coalition of interests and tries to gather all the major actors, starting from regulatory bodies and industrial leaders, to suppliers of complementary technologies, economists, and technical advisors.

Despite high formalisation of standards in the industry, technical excellence and credibility are signalled by the institutional embeddedness in high quality, recognised business envi- 
ronment. This is why SoftCo launched the operations in the business incubator in the UK to start a collaboration with large global players, semiconductor companies from Silicon Valley.

The important institutions at the macro-level of the country and the EU are policies and regulations for supporting technological innovations in SMEs. The company benefits from the public support, including R\&D grants and locations in the technology parks of Poland and abroad, specifically in the developed economies of the EU.

\section{Innovations and Upgrading}

Innovations refer to the product and service, which are new at least to the firm's market. SoftCo accomplished a dominating competitive position in the markets it occupies. Therefore, we can state that it features upgrading. This is a product, functional (new services and product provided to the existing customers), as well as value chain upgrading (the competitive advantage in new value chains introduced through product innovations to the firm's portfolio).

\section{The Role (Position) of SoftCo in Modular Value Chains}

Based on the characteristics of the inter-firm governance, power relations, institutional framework and types of innovation and upgrading we can assert that SoftCo acts within modular governance design with some level of relational value chains with respect to long-term customers from the key industries, i.e., media and energy. The scope of its activities and relationships with buyers and suppliers as well as the types of innovation and upgrading match with a position of a leader firm, according to the GVC typology. Although SoftCo does not meet the market power and size of the major leader firms in the industry, it is growing with a goal to accomplish a similar position.

It remains inconclusive, however, whether the company position is a stage of the development toward the role of a regional or global leader firm in the industry or it is a quite new, emergent pattern of innovative SME functioning in modular value chains. In the first case, the firm will either accomplish the global or regional position as a leader firm or it will fail to achieve it and maybe downgrade to the position of the subcontractor using external technologies. In the second case, SoftCo can establish a new pattern of innovative SME functioning as a medium-sized technology enterprise that might be called a quasi-leader. This would be a position of the firm that grows with the use of global pipelines of large corporations serving as channels of distribution for SoftCo's products in millions of units on a global scale.

Table 1 presents a pattern-matching between the properties of a model lead firm, as described in the GVC, and the properties of SoftCo.

SoftCo demonstrates considerable similarities with the characteristics of a model lead firm in modular value chains. This finding challenges the GVC literature, in which the lead role is predominantly attributed to large companies (Sturgeon, 2002; 2003; Ivarsson \& Alvstam, 2011; Kodama \& Shibata, 2013; Yan et al., 2014). Minor inconsistencies stem from less formalised transactions due to the need to exchange an intense and partially not codified information with customers for whom the firm develops more risky innovations. This is also associated with the incidence of some moderate level of asset adjustments to long-term buyers, which still does not harm the balance of power between the partners. Finally, we observe modular value chain governance with some component of relational governance that is typical of SMEs, as described in the international entrepreneurship literature (Oviatt \& McDougall, 2005; Coviello \& 
Munro, 1997; Coviello, 2006). Another difference is the scope and intensity of standard-setting, more regionally than globally oriented in relation to a model lead firm.

Table 1. Pattern-matching between the properties of a model leader firm and the properties of SoftCo

\begin{tabular}{|l|l|}
\hline \multicolumn{1}{|c|}{ Lead firm properties } & \multicolumn{1}{c|}{ SoftCo's properties } \\
\hline $\begin{array}{l}\text { Inter-firm governance } \\
\text { (modular value chain) }\end{array}$ & $\begin{array}{l}(+;-) \text { (modular with some component } \\
\text { of relational chains) } \\
\text { Transaction complexity high } \\
\text { Transaction formalisation high }\end{array}$ \\
$\begin{array}{l}(+) \\
\text { Capability high }\end{array}$ & $(+;-)$ (high to medium) \\
\hline Power relations balanced & $(+)$ \\
Asset specificity low & $(+;-)$ (low with some incidents of medium) \\
\hline Product innovation dominating and standard & $(+;-)$ (standard setting predominantly with \\
setting & a regional and not the world scope) \\
\hline Product, functional, and value chain upgrading & $(+)$ \\
\hline
\end{tabular}

$(+)$ - the firm's characteristic consistent with the model characteristic; (-) - the firm's characteristic inconsistent with the model characteristic

Source: own elaboration.

\section{The Case of ITServCo}

ITServCo is a company specialised in IT outsourcing services predominantly for larger IT firms that offer proprietary applications and comprehensive information technologies. In the years 2010-2012 is has accomplished a compound growth in revenue and employment of more than $122 \%$, expanding from small to medium-sized company. Established in 2004 with 5 employees, ITServCo increased its employment to 80 people in 2012. In 2014, the number of engineers cooperating directly with the company as subcontractors reached 500 , while the pool of available specialists in the firm's network of 20 IT service firms counted around 950 .

ITServCo focuses on the implementation of product innovations and projects of other large firms. In the beginning of its operations, it was offering a simple "body leasing" service with a "time and material" type of cooperation. This kind of cooperation involved the outsourcing of individual professionals or teams to implement standardised tasks and projects for large IT firms or for IT departments of other corporate clients. By 2015, as a mid-sized firm, ITServCo was able to offer a full range of production functions, such as IT outsourcing, software development, application testing, implementing the solutions of leading IT suppliers, application integration and others. A variety of cooperation types were offered, such as fixed-price projects, when a specific task needs to be implemented for a given payment and according to the specified agenda, time and material, based on the amount of working hours provided by the outsourced team, participation in consortium, consulting, and others.

Up to 2015 , the company was developing organically by increasing the number of customers and cooperating engineers, and by networking with around 20 other IT service firms that offered complementary resources. In 2015, ITServCo formed a capital group by acquiring minority shares in a number of its collaborators and reached the size of a large enterprise. It enabled a comprehensive range of production services offered to large firms focused on product innovations. The expansion of ownership and value added was accompanied by establishing own subsidiaries or joint ventures in the USA and Germany, among others, which made the company operations global. 


\section{The Inter-firm Governance}

\section{Transaction Complexity}

In the beginning of the outsourcing activity, the company dealt with low complexity of transactions. The contracts did not require a large amount of information to be exchanged, as the tasks and projects were standardised and limited merely to "body leasing", i.e., subcontracting the work of engineers for a specific period of time, without taking responsibility for the project or a task. However, introducing new services and forms of cooperation with customers and accomplishing the capacity to implement a full range of production activities (functions) including product development, testing, agile management of projects, consulting, and technical maintenance launched complex transactions with the need to intensely exchange large amounts of information. The complexity is predominantly featured by long-term customers that require a comprehensive range of activities in terms of development, production, and maintenance services. The standard "time and material" services comprise low complexity.

\section{Transaction Formalisation}

High formalisation is associated with both simple contracts and with complex undertakings regarding strictly technological issues. The IT industry features open standards and purposeful provision of access to interfaces and the information on functionalities of specific modules. Therefore, from purely technological point of view, the transactions of ITServCo feature high formalisation. On the other hand, in the case of long-term contracts, we observe the necessity to establish intense exchange of not only codified but also informal and tacit information to better understand the needs of the customer and its business system. To sum up in the long-term contracts we observe a medium (moderate) level of formalisation.

\section{Capability}

At the outset of its activity, ITServCo did not demonstrate high technological capability, being just an outsourcing platform for engineers who predominantly worked in projects supervised by the firm's customers. At that time, the firm demonstrated high governance capabilities, being able to gather a considerable and varied pool of talents and match them with customers needing support in rather standardised activities and tasks. With regard to technological capabilities, the engineers with standard levels of technological skills used to work for subcontracting companies as individuals rather than the ITServCo firm. Therefore, the company did not internalise these individual capabilities as its proprietary pool of resources. The same rules applied to intellectual property resulting from specific contract, namely, the agreements regulated the transfer of intellectual property to subcontracting firms (ITSerCo's customers).

However, recently, the firm has appropriated technological capabilities of the staff by acquiring minority shares in a number of companies cooperating earlier as a network of independent firms. This horizontal quasi-integration with to-date competitors-collaborators was also associated with acquiring intellectual property to products developed for customers and with the extension of services offered to become a "turn-key" supplier with high capability. 


\section{Relationships in the Value Chain and the Scope of Activities}

The company is directed at growth as a provider of production capacity in the area of IT services with some attempts to develop proprietary software, as well. However, it signals the focus on production capacity not to get into a conflict of interest with its customers. These are predominantly other IT large companies that develop proprietary solutions and non-IT firms for whom ITServCo implements larger projects with the use of a comprehensive set of functions. The operations are held both in Poland and abroad, including the USA and Canada, which makes the company an international venture. Its ownership structure differentiates by a large number of minority shares and some majority shares in other IT businesses with complementary human skills. This governance ensures both adequate control and access to resources. Moreover, in the face of the changing demand, it is more flexible in comparison with full ownership.

\section{Power Relations - Asset Specificity}

The IT industry is governed by the rule of open architecture and open standards, however, different levels of freedom in developing and applying standards have evolved. ITServCo works on standards licensed by major IT companies, e.g. Microsoft, Oracle, IBM, and HP, and acquires adequate certificates to apply their solutions. This a medium-level of asset specificity, since standards are widespread and feature network effects from a large number of users. On the other hand, they require the adaptation to terms of licensing about the scope of creative use not to harm legal protection of intellectual property.

By cooperating with branded technology providers, the firm gains credibility among customers and exploits network effects from a global community of users of these branded, lead firms. However, such a cooperation might also be perceived like giving up own brand building and purposefully limiting the development of proprietary product innovations not get into a litigation about the use of standards. Moreover, to avoid the conflict of interests with its powerful customers, the firm develops proprietary software only in product niches neglected by its customers.

\section{Institutional Framework}

The institutional environment of the firm is formed by industry technological standards and rules of cooperation. Moreover, it is affected by legal employment conditions, since its business model remains largely based on hiring external employees to process orders from large customers. These two types of institutions form opportunities, however, they also put burdens on company growth. In the case of industrial standards and rules, these are opportunities for network effects by using standards of high-brand customers and limitations to creative activity and proprietary software. In the case of employment regulations, exploiting the opportunities to subcontracting other businesses was a basis for accomplishing growth.

However, unpredicted changes to these arrangements may be harmful for the entire value chain of ITServCo and its governance capabilities. Reorganizing rules of contracting can have an effect not only on production costs, but also on transaction costs with respect to drafting, negotiating, and renegotiating contracts with suppliers and customers. 
As a technology firm, ITServCo has also benefitted from institutional framework of SME support policy in the area of business incubation (establishing start-ups in a technology park) and technology development.

\section{Innovations and Upgrading}

ITServCo achieved its growth due to a combination and sequence of organisational, process, and product innovations, predominantly new to the firm and not to the market or world. The company was established as an organisational innovation in the area of interorganisational management and it had formed a virtual organisation of engineers. Further organisational innovation consisted in capital engagement in a number of small suppliers to establish a stronger capability base and contracting capacity. In IT services, where tangible assets are not high, even a minority engagement strengthens cooperation and establishes a sense of unity among the network of formerly independent collaborators. This engagement ensured the access to the information on collaborators and provided tools of influence on the employees hired for ITServCo's projects. Moreover, it improved credibility in the perception of customers, who became more confident about the firm's capacity to process complex commissions that required a wide range of skills and infrastructural capacity.

The organisational innovations enabled technological innovations in the area of products/services and processes to launch new functions in the company operations. These were new products/services in the existing value chain that increased value by a comprehensive range of production functions (vertical quasi-integration, from product development, testing, consulting to maintenance). Moreover, process innovations with respect to services provision accompanied the sequence of product innovations, such as agile product development. These predominantly new to the firm (and not to the industry or world) innovations cumulated in a short period of around three to four years. As their joint effect, ITServCo featured product, process, and functional upgrading.

\section{The Role (Position) of ITServCo in Modular Value Chains}

When analysing ITServCo's inter-firm governance, power relations, institutional framework and types of innovation and upgrading, an evolution from market-based and captive value chains to the modular value chain governance with some component of relational governance can be observed. The latter type of governance pertains to long-term customers for whom the firms develops a full range of functions within value chain. The firm activities focus on production capacity delivered to customers who want to implement their projects. The full range of functions it accomplished enables acting as a "turnkey" capacity supplier. To sum up, the inter-firm governance, power relationships with buyers and suppliers, as well as the types of innovation and upgrading match with a position of a contract manufacturer, in the view of the GVC approach.

Alike in the case of SoftCo, this company does not meet the market power and size of the major contract manufacturers. However, due to growth, including international expansion, it has evolved from medium-sized and lowest-tier supplier to a large, quasi-contract manufacturer/producer (we will refer to it as a contract producer or system integrator, considering the service rather than manufacturing activity of ITServCo). This development path will probably lead the firm to the position of a contract producer filling market niches that were left free by largest system integrators and lead firms in the industry. 
Table 2 describes a pattern-matching between the properties of a model contract manufacturer (producer), as described in the GVC, and the properties of ITServCo as a mid-size firm (before the 2015 ownership expansion).

Table 2. Pattern-matching between the properties of a model contract manufacturer (producer) and the properties of ITServCo as a mid-size firm (before the 2015 ownership expansion)

\begin{tabular}{|c|c|}
\hline Contract manufacturer's properties & $\begin{array}{l}\text { ITServCo's properties as a medium-sized } \\
\text { company, before 2015) }\end{array}$ \\
\hline $\begin{array}{l}\text { Inter-firm governance } \\
\text { (modular value chain) } \\
\text { Transaction complexity high } \\
\text { Transaction formalisation high } \\
\text { Capability high } \\
\end{array}$ & $\begin{array}{l}(+;-) \text { (modular with some component } \\
\quad \text { of relational chains) } \\
(+;-) \text { (low to high) } \\
(+;-) \text { (high to medium) } \\
(+)\end{array}$ \\
\hline $\begin{array}{l}\text { Power relations balanced } \\
\text { Asset specificity low }\end{array}$ & $\begin{array}{l}(+) \\
(+;-) \text { (low to medium) }\end{array}$ \\
\hline Process innovation dominating & $(+)$ \\
\hline Process, product, and functional upgrading & $(+)$ \\
\hline
\end{tabular}

$(+)$ - the firm's characteristic consistent with the model characteristic; $(-)$ - the firm's characteristic inconsistent with the model characteristic

Source: own elaboration.

ITServCo's governance position well matches the characteristics of a model contract producer firm in modular value chains with some component of relational governance. Alike in the SoftCo's case, this observation gives a new insight relative to the GVC literature that describes contract producers as predominantly large enterprises (Sturgeon, 2002; 2003; Ivarsson \& Alvstam, 2011; Kodama \& Shibata, 2013 Yan et al., 2014). Some discrepancies exist as the elements of the former focus of the company who was a third-tier supplier in the captive governance, e.g., low transaction complexity still present in "time and material" method of outsourcing. Other differences stem from the service- and not product-intensive business model. ITServCo's model requires less formalised (the presence of high to medium formalisation) and more adaptive (low to medium asset specificity) way of implementing projects. This approach is typical of SME networking that involves interaction and mutual dependence of tangible and intangible resources among partners (Agostino et al., 2015; Aslesen \& Harirchi, 2015; Massini et al., 2010; Alberti et al., 2008; Oviatt \& McDougall, 2005).

\section{CONCLUSIONS}

The paper presented modular value chains as a technological and organisational phenomenon that affects industrial organisation and innovation, and it identified the characteristics and types of SME positions in modular value chains that are associated with innovation development and growth.

The extant literature on global value chains (GVCs) has focused on large firms as major players and sources of product and process innovation in modular value chains (Sturgeon, 2002; 2003; Ivarsson \& Alvstam, 2011; Lee \& Saxenian, 2008; Kodama \& Shibata, 2013; Simms \& Trott, 2014; Yan et al., 2014; Pietrobelli \& Rabellotti, 2006). The impact of the value chain modularisation on the positions as well as pro- 
spects for growth and innovation of SMEs has been unexplored. SMEs are predominantly perceived as third-tier suppliers that occupy lower-value positions (Humphrey \& Schmitz, 2002; 2004a; Belaya \& Hanf, 2014; Lungwitz et al., 2006; Gancarczyk, 2016). However, the international entrepreneurship literature provides an optimistic evidence of innovativeness and growth of small firms (Oviatt \& McDougall, 2005; Coviello \& Munro, 1997; Coviello, 2006; Gancarczyk \& Gancarczyk, 2017).

Our exploratory study of two growth SMEs operating within modular global governance has contributed by identifying a variety of roles that small and mediumsized enterprises may adopt in MVCs and by describing the governance solutions they apply to accomplish innovation and growth.

SME roles in modular value chains range from lowest-tire subcontractors in captive or market-based governance to major roles typical of large players in modular governance, e.g., quasi-lead firms and quasi-contract manufacturers. These two positions feature innovativeness, upgrading and growth, therefore, we propose an analytical generalisation about their governance arrangements. The analytical generalisation describes the inter-firm governance, power relations, and institutional arrangements of a quasi-leader and quasi-contract producer as conducive to innovativeness and expansion.

The quasi-lead company's role is based on inter-firm governance with high transaction complexity, high formalisation that decreases to medium level in the case of long-term customers that require risky innovations, and high technological capability. Power relations are balanced and ensure independence of specific assets, except for long-term customers that need some adjustments to their needs. A quasi-lead firm generates product innovations that are new at least to its national market and represent its proprietary solutions. These innovations provide for a range of upgrading opportunities, from product and process to functional and value chain upgrading. The work of a quasi-leader is more directed at delivering a proprietary product than on service delivery (more product- and less service-intensive).

The quasi-contract manufacturer (system integrator) features high to medium transaction complexity and formalisation. Power relations stem from tailoring the service-intensive activities to the needs of specific customers. This type of role is less directed at developing proprietary standard products since power relations require some level of asset specificity and adjustments to the technology and licensing policy of branded providers of standards and interfaces. A quasi-system integrator delivers process and product innovations that are new to itself rather than to the market or world. However, it explores some niches where proprietary solutions might be developed that are new to the market. The opportunities for upgrading include process and product, as well as functional upgrading to provide a full range of production activities, i.e., to be a "turn-key" supplier of production capacity. Finally, the quasi-contract producer's operations are more service- than product-intensive, therefore, its work needs to be more customer-specific than the work of a quasi-leader.

The above characteristics raise also a question for further research. This is the question whether the roles identified in the case studies can be treated as SME-specific models of participation in modular value chains, or they are only development stages of growth SMEs towards the roles of large firms - major players in modular chains, i.e. 'full' leader firms and 'full' contract manufacturers (system integrators). The current findings do not allow for determining the nature of these roles and this can be treated a limitation of our study. This limitation is also closely linked to qualitative and analytical gener- 
alisation instead of statistical one, as acknowledged earlier in the methodological section. However, we propose that our study establishes a basis for research hypotheses in further, quantitative research. The quantitative research directed at statistical generalization should ultimately resolve the interpretation problem we faced. At this stage, we can propose that both possibilities are feasible. Considering growth aspirations of the entrepreneurs interviewed, they seek to pursue growth and strengthen their positions towards these of market leaders globally or regionally at least. On the other hand, it is also possible that they continue as national market leaders, filling the niches where more adjustments of products and processes to customer needs are relevant. In this vein, they would be providers of products and services that rely on external standards and represent their adjustments to the business systems of customers.

Finally, the paper enables some recommendations as to the role of public policy and spatial, geographic context regarding how to facilitate SME integration into MVCs with a focus on innovativeness and growth. Both firms benefitted from public support in the area of grants and lowering risks by establishing new ventures in business incubators and technology parks. Acting in the global competitive environment provides both opportunities to exploit creativity and cost advantages internationally. On the other hand, it also demands building credibility and recognition through networking and embedding in high-quality business relationships. Such a requirement was especially evident for SoftCo, which acquired recognition and collaboration opportunities by establishing a subsidiary in a technology incubator in the UK. This evidence proves that public policy for technology firms and their international expansion is well targeted and gives prospects for the return from public investment in the form of firm growth and international competitiveness. Specifically, promoting the international networking among local and international institutions, such as science and technology parks, business incubators and innovation relay centres, needs to be emphasised.

\section{REFERENCES}

Agostino, M., Giunta, A., Nugent, J.B., Scalera, D., \& Trivieri, F. (2015). The importance of being a capable supplier: Italian industrial firms in global value chains. International Small Business Journal, 33(7), 708-730.

Ahlin, B., Drnovšek, M., \& Hisrich, R.D. (2014). Exploring the moderating effects of absorptive capacity on the relationship between social networks and innovation. Journal for East European Management Studies, 19(2), 213-235.

Alberti, F.G., Sciascia, S., Tripodi, C., \& Visconti, F. (2008). Entrepreneurial growth in industrial districts. Cheltenham: Edward Elgar.

Aslesen, H.W., \& Harirchi, G. (2015). The effect of local and global linkages on the innovativeness in ICT SMEs: does location-specific context matter?. Entrepreneurship \& Regional Development, 27(9-10), 644-669.

Baldwin, C.Y. (2008). Where do transactions come from? Modularity, transactions, and the boundaries of firms. Industrial and Corporate Change, 17(1), 155-195.

Baldwin, C.Y., \& Clark, K.B. (2000). Design rules: The power of modularity (Vol. 1). Cambridge MA, London: MIT Press.

Barringer, B.R., Jones, F.F., \& Neubaum, D.O. (2005). A quantitative content analysis of the characteristics of rapid-growth firms and their founders. Journal of Business Venturing, 20(5), 663-687. 
Battisti, G., Colombo, M.G., \& Rabbiosi, L. (2014). Simultaneous versus sequential complementarity in the adoption of technological and organisational innovations: The case of innovations in the design sphere. Industrial and Corporate Change, 24(2), 345-382.

Belaya, V., \& Hanf, J.H. (2014). Power and influence in Russian agri-food supply chains: Results of a survey of local subsidiaries of multinational enterprises. Journal for East European Management Studies, 19(2), 160-184.

Campbell, D.T. (1966). In K. R. Hammond (ed.), The psychology of Egon Brunswik (pp. 81-106). New York: Holt, Rinehart \& Winston.

Colfer, L. (2007). The mirroring hypothesis: theory and evidence on the correspondence between the structure of products and organisations. Manuscript, 11(22), 07.

Colfer, L., \& Baldwin, C.Y. (2010). The mirroring hypothesis: Theory, evidence and exceptions. Harvard Business School Finance Working Paper, (10-058).

Coviello, N.E. (2006). The network dynamics of international new ventures. Journal of International Business Studies, 37(5), 713-731.

Coviello, N., \& Munro, H. (1997). Network relationships and the internationalisation process of small software firms. International Business Review, 6(4), 361-386.

Cusmano, L., Mancusi, M.L., \& Morrison, A. (2011). Globalization of production and innovation: how outsourcing is reshaping an advanced manufacturing area. Regional Studies, 44(3), 235-252.

Dobbs, M., \& Hamilton, R.T. (2007). Small business growth: recent evidence and new directions. International Journal of Entrepreneurial Behavior \& Research, 13(5), 296-322.

Eisenhardt, K.M. (1989). Building theories from case study research. Academy of Management Review, 14(4), 532-550.

Eisenhardt, K.M., \& Graebner, M.E. (2007). Theory building from cases: Opportunities and challenges. Academy of Management Journal, 50(1), 25-32.

Ernst, D. (2004). How sustainable are benefits from global production networks? Malaysia's upgrading prospects in the electronics industry. In J.B. Kidd \& F-J. Richter (Eds.), Trust and Antitrust in Asian Business Alliances (pp. 209-230). London, UK: Palgrave Macmillan.

Frenken, K., \& Mendritzki, S. (2012). Optimal modularity: a demonstration of the evolutionary advantage of modular architectures. Journal of Evolutionary Economics, 22(5), 935-956.

Funk, J.L. (2009). The co-evolution of technology and methods of standard setting: the case of the mobile phone industry. Journal of Evolutionary Economics, 19(1), 73-93.

Gancarczyk, M. (2015). Enterprise- and industry-level drivers of cluster evolution and their outcomes for clusters in developed and less developed countries. European Planning Studies, 23(10), 1932-1952.

Gancarczyk, M. (2016). The integrated resource-based and transaction cost approach to the growth process of firms. Journal of Organisational Change Management, 29(7), 1189-1216.

Gancarczyk, M., \& Gancarczyk J. (2016). SME Supplier upgrading during the cooperation life cycle - evidence from Central and Eastern Europe. Journal for East European Management Studies, 21(3), 318-351.

Gancarczyk, M., \& Gancarczyk, J. (2011). Wzrost i internacjonalizacja przedsiębiorstw w klastrach. Organizacja i Kierowanie, 3(146), 59-75.

Gancarczyk, M., \& Gancarczyk, J. (2013). Structural change in industrial clusters-scenarios and policy implications. Studia Regionalia, (35), 111-128.

Gancarczyk, M., \& Zabala-Iturriagagoitia, J.M. (2015). The Process of the Growth of Small and MediumSized Enterprises (SMEs). Journal of Entrepreneurship, Management and Innovation, 11(4), 3-24.

Gancarczyk, M., \& Gancarczyk, J. (in press). Proactive international strategies of cluster SMEs. European Management Journal, doi: http://dx.doi.org/10.1016/j.emj.2017.03.002 
Gangnes, B., \& Van Assche, A. (2004). Modular Production Networks in Electronics: the Nexus between Management and Economics Research. In SMU Economics \& Statistics Working Paper Series, Singapore Management University.

Garud, R., Kumaraswamy, A., \& Langlois, R. (Eds.). (2009). Managing in the modular age: architectures, networks, and organisations. Hoboken, New Jersey: John Wiley \& Sons.

Gereffi, G. (1996). Global commodity chains: new forms of coordination and control among nations and firms in international industries. Competition \& Change, 1(4), 427-439.

Gereffi, G., Humphrey, J., \& Sturgeon, T. (2005). The governance of global value chains. Review of International Political Economy, 12(1), 78-104.

Gilbert, B.A., McDougall, P.P., \& Audretsch, D.B. (2006). New venture growth: a review and extension. Journal of Management, 32(6), 926-950.

Hätönen, J. (2010). Outsourcing and licensing strategies in small software firms: evolution of strategies and implications for firm growth, internationalisation and innovation. Technology Analysis \& Strategic Management, 22(5), 609-630.

Henderson, R.M., \& Clark, K.B. (1990). Architectural innovation: The reconfiguration of existing product technologies and the failure of established firms. Administrative Science Quarterly, 35(1), 9-30.

Hoetker, G. (2006). Do modular products lead to modular organisations?. Strategic Management Journal, 27(6), 501-518.

Huggins, R., \& Johnston, A. (2010). Knowledge flow and inter-firm networks: The influence of network resources, spatial proximity and firm size. Entrepreneurship \& Regional Development, 22(5), 457-484.

Humphrey J., Schmitz H., (2004a). Governance in global value chains, In H. Schmitz (Ed.), Local enterprises in the global economy. Cheltenham: Edward Elgar.

Humphrey, J., \& Schmitz, H. (2004b). Chain governance and upgrading: taking stock. In H. Schmitz (Ed.), Local enterprises in the global economy. Cheltenham: Edward Elgar.

Humphrey, J., \& Schmitz, H. (2002). How does insertion in global value chains affect upgrading in industrial clusters?. Regional Studies, 36(9), 1017-1027.

Ivarsson, I., \& Alvstam, C.G. (2010). Upgrading in global value-chains: a case study of technology-learning among IKEA-suppliers in China and Southeast Asia. Journal of Economic Geography, 11(4), 731-752.

Kaplinsky, R., \& Morris, M. (2001). A handbook for value chain research (Vol. 113). Ottawa: IDRC.

Kaplinsky, R., Morris, M., \& Readman, J. (2002). Understanding upgrading using value chain analysis. Retrieved on April 3, 2017 from http://eprints.brighton.ac.uk/876/1/Understanding _Upgrading_Using_Value_Chain_Analysis.pdf

Kodama, M., \& Shibata, T. (2013). Strategy transformation through strategy innovation - a case of Fanuc. R\&D Management, 44(1), 75-103.

Langley, A. (1999). Strategies for theorizing from process data. Academy of Management Review, 24(4), 691-710.

Langlois, R.N. (2002). Modularity in technology and organisation. Journal of Economic Behavior \& Organisation, 49(1), 19-37.

Lau, A.K. (2011). Critical success factors in managing modular production design: Six company case studies in Hong Kong, China, and Singapore. Journal of Engineering and Technology Management, 28(3), 168-183.

Lee, A.S. (1989). A scientific methodology for MIS case studies. MIS Quarterly, 33-50.

Lee, C.K., \& Saxenian, A. (2008). Coevolution and coordination: a systemic analysis of the Taiwanese information technology industry. Journal of Economic Geography, 8(2), 157-180. 
Lungwitz, R.E., Lee, P., \& Campagna, S. (2006). Co-ordination media in cross-national networks of small and medium-sized enterprises. Journal for East European Management Studies, 11(4), 372-380.

Malecki, E.J. (2010). Global knowledge and creativity: new challenges for firms and regions. Regional Studies, 44(8), 1033-1052.

Massini, S., Perm-Ajchariyawong, N., \& Lewin, A.Y. (2010). Role of corporate-wide offshoring strategy on offshoring drivers, risks and performance. Industry and Innovation, 17(4), 337-371.

McDougall, P.P., \& Oviatt, B.M. (2000). International entrepreneurship: the intersection of two research paths. Academy of Management Journal, 43(5), 902-906.

Mudambi, R. (2008). Location, control and innovation in knowledge-intensive industries. Journal of Economic Geography, 8(5), 699-725.

Munari, F., Sobrero, M., \& Malipiero, A. (2011). Absorptive capacity and localized spillovers: Focal firms as technological gatekeepers in industrial districts. Industrial and Corporate Change, 21(2), 429-462.

OECD, E. (2005). Oslo Manual. Guidelines for Collecting and Interpreting Innovation Data. (3rd ed.). Retrived on November 6, 2013 from: http://www.oecd.org/sti/inno/oslomanualguidelinesforc ollectingandinterpretinginnovationdata3rdedition.htm

Oviatt, B.M., \& McDougall, P.P. (2005). Defining international entrepreneurship and modeling the speed of internationalization. Entrepreneurship Theory and Practice, 29(5), 537-554.

Pavlínek, P. (2012). The internationalization of corporate R\&D and the automotive industry R\&D of East-Central Europe. Economic Geography, 88(3), 279-310.

Penrose, E.T. (1959). The Theory of the Growth of the Firm. Oxford, USA: Oxford University Press.

Pietrobelli, C., \& Rabellotti, R. (2006). Upgrading to compete. Global Value Chains, Clusters, and SMEs in Latin America. Washington, DC: Inter-American Development Bank.

Pietrobelli, C., \& Rabellotti, R. (2011). Global value chains meet innovation systems: are there learning opportunities for developing countries?. World Development, 39(7), 1261-1269.

Pisoni, A., Fratocchi, L., \& Onetti, A. (2013). Subsidiary autonomy in transition economies: Italian SMEs in Central and Eastern European countries. Journal for East European Management Studies, 18(3), 336-370.

Rugraff, E. (2010). Foreign direct investment (FDI) and supplier-oriented upgrading in the Czech motor vehicle industry. Regional Studies, 44(5), 627-638.

Sanchez, R., \& Mahoney, J.T. (1996). Modularity, flexibility, and knowledge management in product and organisation design. Strategic Management Journal, 17(S2), 63-76.

Sanchez, R., \& Mahoney, J.T. (2013). Modularity and economic organisation: concepts, theory, observations, and predictions. In A. Grandori (Ed.), Handbook of economic organisation: integrating economic and organisation theory, (pp. 383-399). Cheltenham, UK: Edward Elgar Publishing Limited.

Silverman, D. (2005). Doing qualitative research. London: Sage.

Simms, C.D., \& Trott, P. (2014). Barriers to the upgrade cycle in a commodity process industry: evidence from the UK packaging industry. R\&D Management, 44(2), 152-170.

Storey, D.J. (1994). Understanding the small business sector. London: Routledge.

Sturgeon, T.J. (2002). Modular production networks: a new American model of industrial organisation. Industrial and Corporate Change, 11(3), 451-496.

Sturgeon, T.J. (2003). What really goes on in Silicon Valley? Spatial clustering and dispersal in modular production networks. Journal of Economic Geography, 3(2), 199-225.

Sturgeon, T., Van Biesebroeck, J., \& Gereffi, G. (2008). Value chains, networks and clusters: reframing the global automotive industry. Journal of Economic Geography, 8(3), 297-321. 
Ulrich K.T., \& Eppinger S.D. (2000). Product design and development (2nd ed.). Boston: Irwin/McGraw-Hill.

Williamson, O.E. (1975). Markets and hierarchies. New York: Free Press.

Williamson, O. (1991). Comparative economic organization: The analysis of discrete structural alternatives. Administrative Science Quarterly, 36(2), 269-296.

Williamson, O.E. (1999). Strategy research: governance and competence perspectives. Strategic Management Journal, 20(12), 1087-1108.

Williamson, O.E. (2002). The theory of the firm as governance structure: from choice to contract. The Journal of Economic Perspectives, 16(3), 171-195.

Williamson, O.E. (2005). The economics of governance. The American Economic Review, 95(2), 1-18.

Winter, J. (2010). Upgrading of TNC subsidiaries: The case of the Polish automotive industry. International Journal of Automotive Technology and Management, 10(2-3), 145-160.

Yan, H.D., Chiang, C., \& Chien, C.S. (2014). From original equipment manufacturing to branding: entrepreneurship, strategic leadership, and Taiwan's firm transformation. International Entrepreneurship and Management Journal, 10(1), 81-102.

Yin, R.K. (2003). Case study research: design and methods (3rd ed.). Thousand Oaks: Sage Publications. 


\section{Authors}

The contribution share of authors is equal each of them.

\section{Marta Gancarczyk}

Associate Professor at the Institute of Economics, Finance and Management, Jagiellonian University in Krakow, Poland. Her research, publication and consulting activities focus on entrepreneurship, firm growth, technology management and commercialization, industrial clusters, and public policy for small and medium-sized enterprises. She is Associate Editor of the international scientific journal 'Journal of Entrepreneurship, Management and Innovation'.

Correspondence to: Dr hab. Marta Gancarczyk, Institute of Economics, Finance and Management, Jagiellonian University in Krakow, ul. prof. S. Lojasiewicza 4, 30-348 Krakow, Poland, e-mail: marta.gancarczyk@uj.edu.pl

\section{Jacek Gancarczyk}

Associate Professor in the Department of Entrepreneurship and Innovation, Jagiellonian University in Krakow, Poland. His research and publication activities are focused on tourism and sport industries, innovation in small and medium-sized tourism enterprises, regional policy for tourism and sport, including clustering in those industries. His is a member of the European Council for Small Business and Entrepreneurship (ECSB).

Correspondence to: Dr. Jacek Gancarczyk, Institute of Entrepreneurship, Jagiellonian University in Krakow, ul. prof. S. Lojasiewicza 4, 30-348 Krakow, Poland, e-mail: jacek.gancarczyk@uj.edu.pl

\section{Joanna Bohatkiewicz}

PhD student of economics at Jagiellonian University, Financial Director, EKKOM Sp. z o.o. Her research interests include Knowledge-Intensive Business Services, clusters, modularisation, global value chains, crisis management, controlling and liquidity management.

Correspondence to: Joanna Bohatkiewicz, M.A., Institute of Economics, Finance and Management, Jagiellonian University in Krakow, ul. prof. S. Lojasiewicza 4, 30-348 Krakow, Poland, e-mail joanna.bohatkiewicz@gmail.com

\section{Acknowledgements and Financial Disclosure}

The empirical research presented in this article is a result of the project financed by Polish National Science Centre (Narodowe Centrum Nauki) - Decision no. DEC-2013/09/B/HS4/01938. The draft version of the paper was presented at the conference "Entrepreneurship in Modern Economy", March 16-17, 2017, Gdansk Technical University, based on the funds from Polish Ministry of Science and Higher Education supporting statutory activities of the Faculty of Management and Social Communication, Jagiellonian University, Krakow, Poland.

The authors would like to thank the anonymous referees for their useful comments, which allowed to increase the value of this article.

\section{Copyright and License}

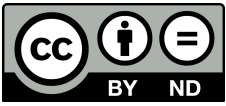

This article is published under the terms of the Creative Commons

Attribution - NoDerivs (CC BY-ND 4.0) License

http://creativecommons.org/licenses/by-nd/4.0/ 
